\title{
An Analysis of Factors Influencing Indonesia's Leading Agricultural Commodities Export to India
}

\author{
Ibnu Muchtar Rosyidi ${ }^{1 *}$, Heru Irianto $^{2}$ and Sutrisno Hadi Purnomo ${ }^{3}$ \\ ${ }^{1}$ Master Student in Agribusiness, Postgraduate Program, Universitas Sebelas Maret, Surakarta, \\ Indonesia; ${ }^{2}$ Department of Agribusiness, Faculty of Agriculture, Universitas Sebelas Maret, \\ Surakarta, Indonesia; ${ }^{3}$ Department of Animal Husbandry, Faculty of Agriculture, \\ Universitas Sebelas Maret, Surakarta, Indonesia \\ *Corresponding author: ibnu.mr94@gmail.com
}

\begin{abstract}
Indonesia's trade balance to India had been decreasing since 2013. That has been affected by the downward trend in agricultural export value of Indonesia. This problem has raised Government's attention to increase the export performance. This research aimed to analyze the determinants of Indonesia's leading agricultural commodities export to India. Panel data regression model was explored to analyze secondary data of the range year 2001 to 2017. The factors examined in this study were India's real Gross Domestic Product (GDP) per capita, Rupiah exchange rate, export price of Indonesia agricultural commodities and India's import tariff. Model testing used the Chow, Hausman and Lagrange tests to compare and select the best model. The determinant of the variables testing used statistical and classical assumption tests. The results showed that India's real GDP per capita has positive influence to the export value which means an increase in the purchasing power of trading partners would increase the value of exports. The Rupiah exchange rate has negative influence to the export value which means that the depreciation of rupiah to dollar causes a decrease in the export value. The export price of Indonesia's agricultural commodities have positive influence on the export value, however the tariff has no effect. The policy that can be suggested to the government is to provide support and encourage domestic producers to increase exports to India.
\end{abstract}

Keywords: agricultural commodities; agricultural trade; exchange rate of rupiah; GDP

Cite this as: Rosyidi, I. M., Irianto, H., \& Purnomo, S. H. (2021). An Analysis of Factors Influencing Indonesia's Leading Agricultural Commodities Export to India. Caraka Tani: Journal of Sustainable Agriculture, 36(1), 135143. doi: http://dx.doi.org/10.20961/carakatani.v36i1.39366

\section{INTRODUCTION}

Indonesia as an open economy country has long been conducting trade cooperation between countries. Economic relations between countries is an important factor that affects the conditions of each country. Every country has demand that must be filled to advance its economy. However, limited resources force a country to conduct trade cooperation between countries. International trade cooperation can also improve the economy. Differences in natural resources, climate, geographic location, knowledge, human resources and technology make countries doing international trade to fill domestic demand. Trade between countries also generates foreign exchange to increase the economy (Krugman and Obstfeld, 2005).

International trade can increase the consumption capacity of a country. It also tends to increase the distribution of income and prosperity in domestic and international countries. Countries with comparative advantages can take advantage of international trade. It can

\footnotetext{
* Received for publication January 23, 2020

Accepted after corrections January 7, 2021
} 
increase the value of exports which will have an impact on increasing investment resulting in additional employment. This condition causes the export performance of a country to be optimized to get the maximum benefit from trade between countries (Ramayani, 2015).

International trade, especially agriculture, faces challenges in providing safe and nutritious food, increasing urbanization and income. Agricultural trade must develop to match the growing demand for food in both developed and developing countries. In addition, agricultural trade plays a role in ensuring the sustainability of natural resources and biodiversity (Food and Agriculture Organization, 2018).

One of the countries which is Indonesia's main trading partner is India. The large population of India and the mastery of information technology can become a potential market for exports of Indonesian agricultural commodities in the future (Kustiari and Hermanto, 2018). India is well known as the second most populous country in the world with a population of 1.3 billion in 2017. India's economic growth rate is about $7 \%$ and a Gross Domestic Product (GDP) of more than US\$ 2,000 trillion year-1 (World Bank, 2018). The Indian government's decision to support manufacturing to create jobs in the service, agriculture and industrial sectors has become India's fundamental economic strength. This makes India a very potential market for Indonesian exports. Countries with large economies have a large import capacity as well (Krugman and Obstfeld, 2005). In addition, the higher the level of income in importing countries led to consumers in importing countries to buy more kinds of goods from exporting countries (Van den Berg, 2016).

During the 2013-2017 period, India was among the top 5 of Indonesia's main export partners. The economic relations between Indonesia and India are of great benefit to both countries. This can be seen from Indonesia's trade balance which experienced a surplus during the 2013-2017 period (World Bank, 2018). However, the non-oil and gas sector showed a higher value than oil and gas, which showed a negative trend $(-0.1 \%)$. Among the leading commodities in the non-oil and gas sector traded between Indonesia and India are agricultural commodities. Some of Indonesia's leading agricultural commodities that are well-known in the world trade rankings including rubber, oil palm, cocoa and coffee (Kustiari and Hermanto, 2018; Reynalto, 2019). Although the trade surplus, but during the period 20132017, the balance of trade in agricultural commodities Indonesia decreased by $-0.015 \%$. The downward trend in the trade balance provides a signal for the government to anticipate various efforts to improve export performance so as to the trade balance trend (Kementrian Perdagangan, 2018).

One of the efforts to improve export performance is by analyzing the influence of domestic and foreign economic variables. Variables that can affect exports such as export prices, per capita income and currency exchange rates (Boansi, 2014; Purnomowati et al., 2015). An increase in the export selling price of a commodity will reduce the demand for that commodity (Girsang et al., 2018). However, in this study, an increase in the price of export commodities positively increases the export value of these commodities. This is an indication that Indonesia's export commodities are highly competitive (Boansi, 2014; Hong, 2016). An increase in the income of the export destination country can also increase the purchasing power of the country so that it can positively affect the increase in export demand (Gul and Yasin, 2011; Wahyudi et al., 2015; Gururaj et al., 2016; Akhmadi, 2017; Cheng et al., 2019).

The export value is affecting the exchange rate; exports increase when there is a depreciation and decrease when there is an appreciation (Orden, 2002). However, fluctuations and the tendency of weakened exchange rates in developing countries have led to a decline in export demand, especially for inelastic commodities such as agricultural commodities (Hall et al., 2010; Sertoglu and Dogan, 2016). In addition, the existence of import policies, such as imposing import tariffs to destination countries, can decrease the domestic export performance. High import tariffs can lead to high prices for imported goods so that consumers will prefer cheaper domestic products (Elsheikh et al., 2015; Amity et al., 2019). According to Uzunoz and Akcay (2009), Djoni et al. (2013), Gururaj et al. (2016) and Karagöz (2016) regression analysis can be used to determine the factors that influence export demand.

The purpose of this study is to analyze the factors that influence the export demand for 
Indonesia's leading agricultural commodities to India. The results of this study are expected to provide an overview of the state of Indonesian agricultural exports to India. So that these results can provide additional references for the policy makers in determining future policies related to agricultural commodity exports.

\section{MATERIALS AND METHOD}

The type of data used in this study is panel data. The time-series data used are annual data for 17 years (2001-2017) including export data from the World Trade Organization (WTO), GDP per capita and exchange rates from the World Development Indicators (WDI), Export data from International Trade Centre (ITC) Trademap and Tariff import from the World International Trade Solution (WITS).
Cross section data is data exports of Indonesia's leading agricultural commodities to India (WTO, 2012). The research was started by sorting the seven agricultural commodities (HS6) based on the highest export value during the 2001-2017 period, namely crude palm oil (HS151110), Palm oil and its fractions (HS151190), Rubber (HS400122), crude palm kernel and babassu oil (HS151321), Wood pulp (HS470329), Cashew nuts (HS080131) and Pepper (HS090411) (ITC, 2019). Based on those seven commodities, panel data regression analysis was done by using STATA software to find out the factors influencing Indonesia's leading agricultural commodities export to India. According to Salvatore (2014) panel data analysis using a basic model as follows: Description:

$$
X_{i t}=\beta_{0 \mathrm{i}}+\beta_{1}(\text { RGDPCJ })_{i t}+\beta_{2}(\text { REXR })_{i t}+\beta_{3}(\text { EXPRICE })_{i t}+\beta_{4}(\text { TARIFJ })_{i t}+\varepsilon_{i t}
$$

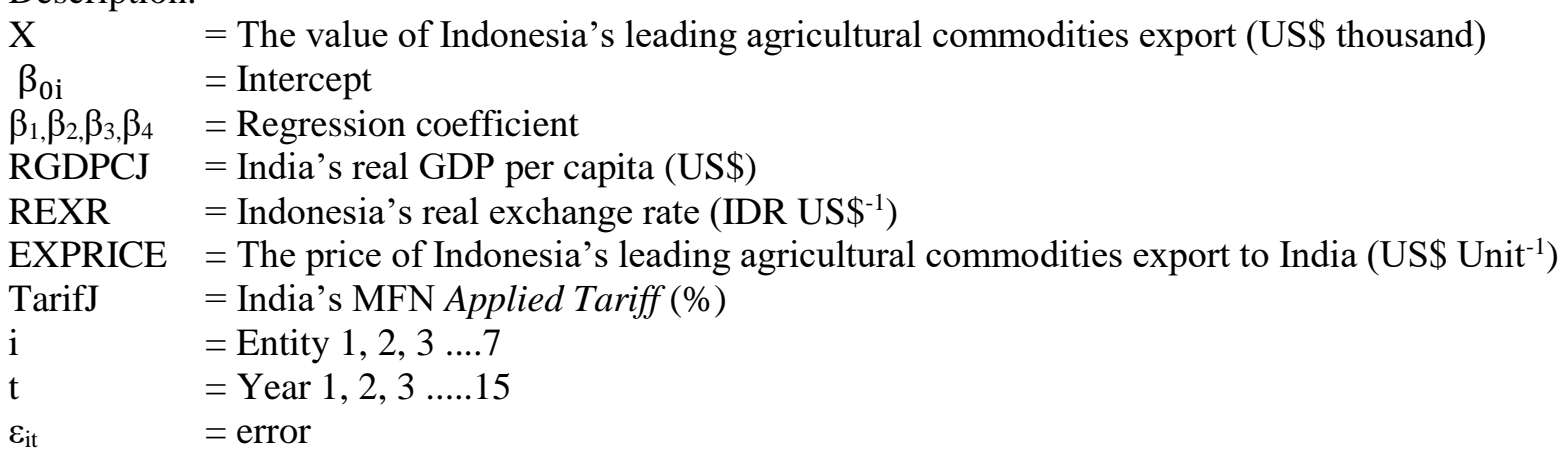

However, to increase the resilience of the regression model and avoid the problem of classical assumption tests, the model was transformed into a linear logarithm. The addition of natural logarithms on both sides of the model above was used to form a new logarithmic model (Sheldon et al., 2013; Cheng et al., 2019).

$$
\mathrm{LnX}_{\mathrm{it}}=\beta_{0 \mathrm{i}}+\beta_{1} \ln (\mathrm{RGDPCJ})_{\mathrm{it}}+\beta_{2} \ln (\mathrm{REXR})_{\mathrm{it}}+\beta_{3} \ln (\text { EXPRICE })_{\mathrm{it}}+\beta_{4} \ln (1+\mathrm{TARIFJ})_{\mathrm{it}}+\varepsilon_{\mathrm{it}}
$$

Estimation in panel data model could use one of three models namely common effect/pooled least square, fixed effect and random effect model. The best model determination was tested by using Chow test, Hausman test and Lagrange Multiplier test. After the best model chosen, it was continued with statistical criteria and classical assumption test. Statistical criteria test covered $\mathrm{R}$ squared test, $\mathrm{F}$ test and $\mathrm{t}$ test, while classical assumption test covered heteroscedasticity test and multicollinearity test. Classical assumption test was done to get model BLUE (Best Linear Unbiased Estimator).

\section{RESULTS AND DISCUSSION}

The trade between Indonesia and India could sustain because both parties gain advantages from this activity. During the period of 2001-2017, Indonesia's leading exports to India for agricultural commodities were crude palm oil, palm oil and its fractions, natural rubber, crude palm kernel and babassu oil, pulp, cashew nut and pepper (International Trade Centre, 2019). The trade during this period had fluctuated. This condition was influenced by some economic variable 
in the two countries like endowment factors and price index. In this study, the factors analyzed that affect trade were the real GDP of India per capita, the REXR of Indonesia, export prices of leading agricultural commodities and trade tariffs.

Figure 1. India's RGDPCJ 2001-2017 in US\$ shows that during the 2001-2017 period, India's per capita real GDP condition had increased from year to year. In 2001, India's RGDPCJ value was US\$ 785 and reached US\$ 1964 in 2017. This GDP had doubled in 17 years. India's high per capita GDP had influenced by manufacturing and service performance (Sinha and Singariya, 2015). A higher per capita GDP has a positive and significant effect on relative export competitiveness. In the long run, it will strengthen Country's exports to trading partners (Narayan and Bhattacharya, 2019).
Figure 2. Indonesia's REXR in US \$ shows that Indonesia's REXR against the US dollar had fluctuated but tend to be appreciated. Indonesia's currency value had shown that the economy of Indonesia had grown. During this period, the Indonesian economy had improved so that it could improve the rupiah exchange rate. Appreciation of a country's trading partners exchange rate is beneficial to an exporting economy due to its positive impact on the volume of exportation to its trading partners when the depreciation of a country's trading partners exchange rate reduces the volume of exportation by the exporting country to its trading partners (Yunusa, 2020). While other factors like the export price and the Indonesia's leading agricultural commodities trade tariff to India had fluctuated according to the traded commodities.

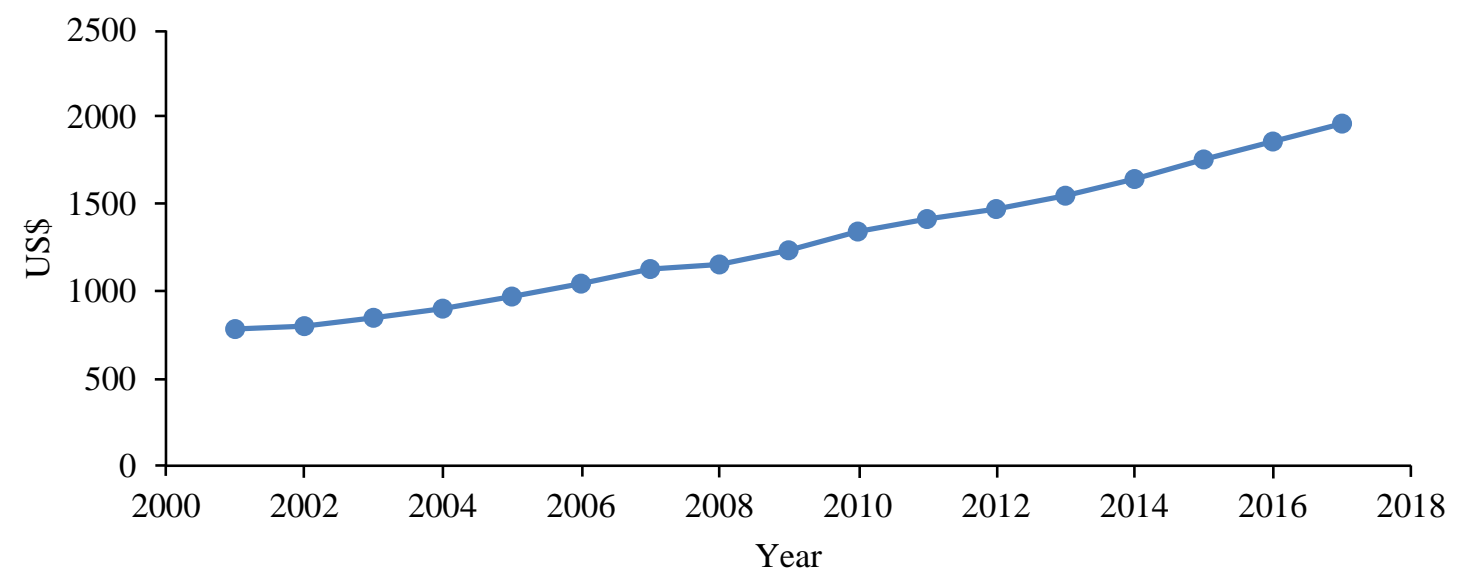

Figure 1. India's RGDPCJ 2001-2017 in US\$

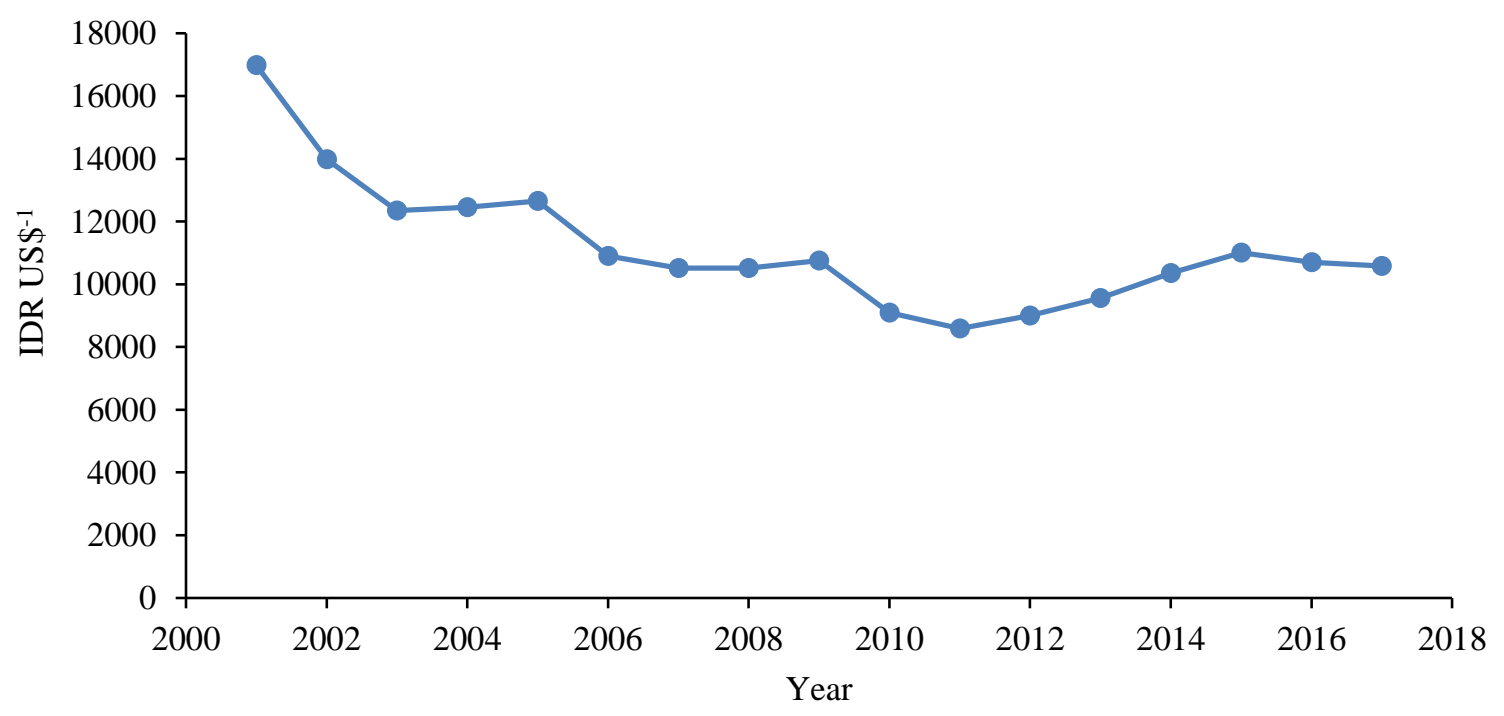

Figure 2. Indonesia's REXR in US\$ 
These factors were analyzed by using panel data regression. The results of the test to select the panel data regression model as follows Table 1.

Table 1. Panel data regression model test

\begin{tabular}{lc}
\hline \multicolumn{1}{c}{ Test } & Probability \\
\hline Chow test & $0.000^{* * *}$ \\
Hausman test & $0.000^{* * *}$ \\
Lagrange multiplier test & $0.000^{* * *}$ \\
\hline
\end{tabular}

\section{Chow test}

Chow test probability valued 0.000 smaller than alpha 0.05. This shows that the fixed effect model is more suitable than the random effect model.

\section{Hausman test}

The Hausman test probability is 0.000 smaller than alpha 0.05. This shows that the fixed effect model is better than the random effect model.

\section{Lagrange multiplier test}

Lagrange multiplier test probability is worth 0.000 smaller than alpha 0.05 . This shows that the random effect model is better than the pooled least square model.

Based on these three tests shown in Table 1, it can be concluded that the best model in this research was fixed effect model. After identifying the best model, the test can be continued to find out the statistical criteria and classical assumption test (Table 2).

Table 2. The result of panel data regression analysis

\begin{tabular}{lcclc}
\multicolumn{1}{c}{ Variable } & Coefficient & t statistic & \multicolumn{1}{c}{ Prob } & Vif \\
\hline RGDPCJ & 1.121041 & 1.93 & $0.056^{*}$ & 2.16 \\
REXR & -1.8342 & -2.23 & $0.028^{* *}$ & 2.08 \\
EXPRICE & .8319358 & 2.74 & $0.007^{* * *}$ & 1.05 \\
TarifJ & .0029223 & 0.04 & $0.969^{\mathrm{NS}}$ & 1.02 \\
Cons & 17.30092 & 3.32 & 0.001 & \\
R square & 0.6875 & & & \\
F & & & $0.0000^{* * *}$ & \\
Breusch-Pagan / & & & 0.3439 & \\
\hline
\end{tabular}

Note: $*=$ Significant in the trustworthiness level $90 \% ; * *=$ Significant in the trustworthiness level $95 \% ; * * *=$ Significant in the trustworthiness level $99 \%{ }^{\text {NS }}=$ insignificant

The large population of India causes the demand for Indonesia's agricultural commodities export to be varied. The ongoing trade in large scale can be influenced by the India's RGDPCJ, Indonesia's REXR, Indonesia's EXPRICE and India's Tarifj. It can be seen from the research findings in $\mathrm{F}$ test which showed that the probability of $\mathrm{F}$ test was 0.000 less than alpha 0.01 . The result of $F$ test showed that the independent variable altogether significantly influenced the dependent variable with the trustworthiness level of $99 \%$.

Based on the result of the regression test, it can be seen that $\mathrm{R}$ squared value was 0.6875 .
This figure showed that the export value can be explained by The India's RGDPCJ, Indonesia's REXR, Indonesia's EXPRICE and agricultural commodities import tariff in India at $68.75 \%$, the remaining $31.25 \%$ was explained by other variables outside the research model.

In $\mathrm{t}$ test, the independent variable that individually really influences the export value of Indonesia's leading agricultural commodities to India was the India's RGDPCJ, Indonesia's REXR and EXPRICE. While the India's Tarifj did not significantly influence the Indonesia's leading agricultural commodities export value to India. The Model that can be made as follows:

$$
\begin{aligned}
\operatorname{LnX}_{i t}= & 17.30092+1.121041 \text { RGDPCJ }_{i t}-1.8342 \text { REXR }_{i t} \\
& +0.8319358 \text { EXPRICE }_{i t}+\beta_{4} \ln \left(1+0.0029223 \text { TARIFJ }_{i t}+\varepsilon_{i t}\right.
\end{aligned}
$$

The constant value of 17.30092 indicates that the initial export demand for Indonesia's leading agricultural commodities to India is US\$ 17,300.92. The independent variable of the India's RGDPCJ had probability value 0.056 or less than alpha 0.1 which meant giving a significant influence to the dependent variable of Indonesia's leading agricultural commodities export value to India in the trustworthiness level $90 \%$. This variable has a coefficient value 
1.121041 which means giving a positive influence to the export value of Indonesia's leading agricultural commodities to India.

If the India's RGDPCJ increased by $1 \%$, it would make the Indonesia's leading agricultural commodities export to India reached up to $1.121041 \%$. According to Van den Berg (2016), a country's export function shows the relationship between exports and national income. Increased income, imports will also increase. On the other hand, a country's exports are imports for trade partners. Exports do not depend on the level of the national income of the exporter, but the national income of trade partners. This result is in accordance with research of Gul and Yasin (2011), Wahyudi et al. (2015), Gururaj et al. (2016) and Akhmadi (2017) It can be seen in India's economy which continues to improve causing increased purchasing power of its people so as to increase the value of exports of leading agricultural commodities from Indonesia to India. In 2001 India's GDP was US\$ 485 billion and had an annual increase of around $4-7 \%$ year $^{-1}$ to US\$2,653 trillion in 2017. During this period, the proportion of India's imports to GDP also had increased from $13.45 \%$ or US\$ 65 billion to $21.94 \%$ or US\$ 582 billion (World Bank, 2018).

The independent variable of Indonesia's REXR had a probability value of 0.028 or less than alpha 0.05 which means giving significant influence to the dependent variable of Indonesia's leading agricultural commodities export value to India with the trustworthiness level $95 \%$. This variable has a coefficient value -1.8342 which means giving a negative influence to the value of Indonesia's leading agricultural commodities export to India. If there was a $1 \%$ depreciation of rupiah exchange rate. It would cause an increase in the value of Indonesia's leading agricultural commodities export to India by -1.8342 . The decreased real exchange rate indicated the appreciation for US\$, whereas if there was an increase then it showed that depreciation of rupiah to US\$.

The negative influences in this research showed that the depreciation of rupiah to dollar causes a decrease in the export value. The depreciation that occurred could cause inflation in domestic so that it could increase the price of products in domestic which was used to produce export goods. In a long time, depreciation indirectly made producers spend more cost in production so that it has an impact on the increase of export goods prices. Consumers would decrease the number of purchase if the price of goods increased (Kahfi, 2016; Lubis, 2016; Akhmadi, 2017; Riyani et al., 2018).

The independent variable of Indonesia's EXPRICE had the probability value 0.007 or less than alpha 0.01 which means giving a significant influence to the dependent variable of Indonesia's leading agricultural commodities export to India in the trustworthiness level $99 \%$. This variable has a coefficient value 0.8319358 which means giving a positive influence to the value of Indonesia's leading agricultural commodities export to India. The coefficient is less than one indicating that the demand is inelastic.

According to Mazurek et al. (2019) the law of demand reads that the higher the price of an item will reduce the demand for that item. However, if the item is very important, necessary and of high competitiveness, then the item will be purchased as needed. This happens to a country's needs for imported agricultural commodities which are highly needed to meet domestic needs (Boansi, 2014; Hong, 2016). India, which is supported by a constantly improving economy, has made the country have sufficient purchasing power to continue importing agricultural commodities from Indonesia as needed even though the prices of these export commodities have increased. In 2001 the export value of Indonesian palm oil to India was US\$ 1.5 billion, increasing to US\$ 3 billion in 2017, even though during that period the Indonesian crude palm oil price was also increased from US\$ 216 ton $^{-1}$ to US\$ 663 ton $^{-1}$ (World Bank, 2018).

Independent variable of the India's Tarifj had probability value of 0.969 or bigger than alpha 0.1 which means giving no significant influence to the dependent variable of Indonesia's leading agricultural commodities export value to India. The charge of import tariff will increase the price of export goods within the importing country. However, the increase of Indian purchasing power and the needs to Indonesia's leading agricultural export commodities caused the charge of import tariff which had no influence to the India's import value. Large-scale importing companies are not affected by the import tariffs that are imposed (Mohamad, 2012; Albornoz et al., 2020).

Multicollinearity and heteroscedasticity test was done in the classical assumption test. Based on the results, it revealed that all independent variable has value VIF $<4$ which showed no 
multicollinearity problems (Javed et al., 2014). Whereas the result of heteroscedasticity test showed the probability of Breusch-Pagan/ Cook-Weisberg valued at 0.3439 or bigger than alpha 0.05 which means there were no heteroscedasticity problems (Breusch and Pagan, 1979).

\section{CONCLUSIONS}

The most interesting finding in this study is the GDP per capita of India and the export price has a positive effect on the export value of Indonesia's leading agricultural commodities. These findings indicate that Indonesia's export commodities are urgently needed, important and highly competitive. This makes India a very potential export market because it is one of Indonesia's main importers. India's rapid economic growth will have a positive effect on trade in the future. This opportunity can be used by the Indonesian government to provide support and encourage domestic producers to increase exports to India.

\section{REFERENCES}

Akhmadi, H. (2017). Assessment the impact of ASEAN Free Trade Area (AFTA) on exports of Indonesian agricultural commodity. AGRARIS: Journal of Agribusiness and Rural Development Research, 3(1), 9-14. https://doi. org/10.18196/agr.3139

Albornoz, F., Brambilla, I., \& Ornelas, E. (2019). The impact of tariff hikes on firm exports. In Mimeo. Retrieved from https://sistemas. colmex.mx/Reportes/LACEALAMES/LACE A-LAMES2019_paper_496.pdf

Amity, M., Redding, S. J., \& Weinstein, D. E. (2019). The impact of the 2018 tariffs on prices and welfare mary. Journal of Economic Perspectives, 33(4), 187-210. https://doi.org/ 10.1257/jep.33.4.187

Boansi, D. (2014). Determinants of agricultural export trade: Case of fresh pineapple exports from Ghana. British Journal of Economics, Management \& Trade, 4(11), 1736-1754. https://doi.org/10.9734/bjemt/2014/10773

Breusch, T. S., \& Pagan, A. R. (1979). A simple test for heteroscedasticity and random coefficient variation. Econometrica, 47(5), 1287-1294. https://doi.org/10.2307/1911963
Cheng, B., Liu, S., Xiong, L., Wang, F., Qin, G., Yue, D., Zhang, H., \& Yu, C. (2019). Identifying the influencing factors on the quality of China's forestry exports. Forestry Economics Review, 1(1), 2-16. https://doi.org/ 10.1108/fer-04-2019-0011

Djoni, D. D., Atmaja, U., \& Fauzi, A. (2013). Determinants of Indonesia's crude coconut oil export demand. Journal of Economics and Sustainable Development, 4(14), 2222-1700. Retrieved from https://www.iiste.org/Journals /index.php/JEDS/article/view/7826

Elsheikh, O. E., Elbushra, A. A., \& Salih, A. A. A. (2015). Economic impacts of changes in wheat's import tariff on the Sudanese economy. Journal of the Saudi Society of Agricultural Sciences, 14(1), 68-75. https:// doi.org/10.1016/j.jssas.2013.08.002

Food and Agriculture Organization. (2018). The state of agricultural commodity markets 2018. Retrieved from http://www.fao.org/ publications/soco/en/

Girsang, L., Sukiyono, K., \& Asriani, P. S. (2018). Error correction model for Pakistan export demand for Indonesia's Crude Palm Oil (CPO). Journal of Agricultural Science, 1, 6877. Retrieved from https://ejournal.unib.ac.id/ index.php/jagritropica/article/view/5588

Gul, N., \& Yasin, H. M. (2011). The trade potential of Pakistan: An application of the gravity model. The Lahore Journal of Economics, 16(1), 23-62. https://doi.org/ 10.35536/lje.2011.v16.i1.a2

Gururaj, B., Satishkumar, M., \& Kumar, M. K. A. (2016). Analysis of factors affecting the performance of exports in India. International Journal of Agriculture, Environment and Biotechnology, 9(4), 613-616. https://doi.org/ 10.5958/2230-732x.2016.00079.6

Hall, S., Hondroyiannis, G., Swamy, P. A. V. B., Tavlas, G., \& Ulan, M. (2010). Exchangerate volatility and export performance: Do emerging market economies resemble industrial countries or other developing countries? Economic Modelling, 27(6), 15141521. https://doi.org/10.1016/j.econmod.2010 .01 .014

Hong, T. T. K. (2016). Effects of exchange rate and world prices on export price of 
Vietnamese coffee. International Journal of Economics and Financial Issues, 6(4), 1756-1759. Retrieved from https://www. econjournals.com/index.php/ijefi/article/view/ 2792

International Trade Centre (ITC). (2019). Trade Map. Retrieved from https://www.trademap. org

Javed, T., Younas, W., \& Imran, M. (2014). Impact of capital structure on firm performance: Evidence from Pakistani Firms. International Journal of Academic Research in Economics and Management Sciences, 3(5), 125-144. https://doi.org/ 10.6007/ijarems/v3-i5/1141

Kahfi, A. S. (2016). Determinants of Indonesia's exports of manufactured: A Panel data analysis. Buletin Ilmiah Litbang Perdagangan, 10(2), 187-202. https://doi.org/10.30908/bilp. v10i2.54

Karagöz, K. (2016). Determining factors of Turkey's export performance: An empirical analysis. Procedia Economics and Finance, 38, 446-457. https://doi.org/10.1016/s22125671(16)30216-7

Kementrian Perdagangan. (2018). Neraca Perdangangan. Retrieved from https://statistik .kemendag.go.id/indonesia-trade-balance

Krugman, P. R., \& Obstfeld, M. (2005). International economics: Theory and policy ( $7^{\text {th }}$ edition). New York: Pearson Education.

Kustiari, R., \& Hermanto, N. (2018). Impacts of Indonesia-India free trade agreements on agricultural sector of Indonesia: A CGE analysis. Jurnal Agro Ekonomi, 35(1), 33-48. https://doi.org/10.21082/jae.v35n1.20 $17.33-48$

Lubis, A. (2016). Analisis faktor yang mempengaruhi kinerja ekspor Indonesia. Jurnal Akuntansi \& Auditing, 13(1), 80-96. https://doi.org/10.30908/bilp.v4i1.144

Mazurek, J., García, C. F., \& Rico, C. P. (2019). The law of demand and the loss of confidence effect: An experimental study. Heliyon, 5(11), E02685. https://doi.org/ 10.1016/j.heliyon.2019.e02685

Mohamad, J. (2012). The Impact of tariff reductions on real imports in Malaysia from
1980-2010. Cambridge Business \& Economics Conference. Retrieved from http://www.gcbe. us/2012_CBEC/data/Juita\%20Mohamad.docx

Narayan, S., \& Bhattacharya, P. (2019). Relative export competitiveness of agricultural commodities and its determinants: Some evidence from India. World Development, 117, 29-47. https://doi.org/10.1016/j.world dev.2018.12.013

Orden, D. (2002). Exchange rate effects on agricultural trade. Journal of Agricultural and Applied Economics, 34(2), 303-312. https:// doi.org/10.1017/S1074070800009056

Purnomowati, H. D., Darwanto, D. H., Widodo, S., \& Hartono, S. (2015). Analisis permintaan karet alam Indonesia di pasar internasional. AGRARIS: Journal of Agribusiness and Rural Development Research, 1(2), 136-148. https:// doi.org/10.18196/agr.1217

Ramayani, C. (2015). Pengaruh investasi pemerintah, investasi swasta, inflasi, eksport, tenaga kerja dan produktivitas tenaga kerja terhadap pertumbuhan ekonomi di Indonesia. Economica, 1(2), 203-207. https://doi.org/ 10.22202/economica.2013.v1.i2.120

Reynalto, A. E. (2019). Factors affecting the performance of Indonesia's crude palm oil export. Agroland: The Agricultural Sciences Journal, 6(2), 89-99. Retrieved from http://jurnal.untad.ac.id/jurnal/index.php/Agro landInternational/article/view/15046

Riyani, R., Darsono, D., \& Ferichani, M. (2018). Analisis permintaan ekspor komoditas pertanian Indonesia oleh pasar Tiongkok. AGRARIS: Journal of Agribusiness and Rural Development Research, 4(2), 120-128. https://doi.org/10.18196/agr.4267

Salvatore, D. (2014). International economics: trade and finance (11th ed.). Hoboken, New Jersey, US: John Wiley and Sons, inc.

Sertoglu, K., \& Dogan, N. (2016). Agricultural trade and its determinants: Evidence from bounds testing approach for Turkey. International Journal of Economics and Financial Issues, 6(2), 450-455. Retrieved from http://www.econjournals.com

Sheldon, I., Mishra, S. K., Pick, D., \& Thompson, S. R. (2013). Exchange rate uncertainty 
and US bilateral fresh fruit and fresh vegetable trade: An application of the gravity model. Applied Economics, 45(15), 20672082. https://doi.org/10.1080/00036846.2011. 650330

Sinha, N., \& Singariya, M. R. (2015). Relationships among per capita gdp, agriculture and manufacturing sectors in India. Journal of Finance and Economics, 3(2), 36-43. https://doi.org/10.12691/jfe-3-2-2

Uzunoz, M., \& Akcay, Y. (2009). Factors affecting the import demand of wheat in turkey. Bulgarian Journal of Agricultural Science, 15(1), 60-66. Retrieved from https://www.agrojournal.org/15/01-08-09.pdf

Van den Berg, H. (2016). International economics: A heterodox approach $\left(3^{\text {th }}\right.$ Edition). New York: Taylor and Francis. https://doi.org/10.4324/9781315671611

Wahyudi., T., Anggita., S., \& Riyandi, S. (2015). The gravity model of Indonesian bilateral trade. International Journal of Social and Local Economic Governance, 1(2), 153 -156. https://doi.org/10.21776/ub.ijleg.2015. 001.02 .9

World Bank. (2018). World bank economic database. Retrieved from https://data.world bank.org

World Trade Organization (WTO). (2012). A practical guide to trade policy analysis. A Practical Guide to Trade Policy Analysis. https://doi.org/10.30875/131552a5-en

Yunusa, L. A. (2020). Exchange rate volatility and Nigeria crude oil export market. Scientific African, 9, e00538. https://doi.org/10.1016/j. sciaf.2020.e00538 